\title{
APPLE MAGGOT (DIPTERA: TEPHRITIDAE) MONITORING IN AN APPLE PEST MANAGEMENT PROGRAM ${ }^{1}$
}

\author{
W. H. Reissig and J. P. Tette \\ New York State Agriculutral Experiment Station, Geneva, New York 14456
}

\begin{abstract}
Can. Ent. 111: 621-625 (1979)

Traps were used to monitor the emergence and seasonal activity of apple maggot flies, Rhagoletis pomonella (Walsh), in unsprayed habitats, and in selected commercial blocks and farms in the New York apple pest management program to determine the need and timing of control sprays. An average of 69,43 , and $43 \%$ fewer sprays and 71,47 , and $57 \%$ less insecticides were applied for apple maggot control, respectively, in single blocks monitored in 1976, 1977, and farms monitored in 1977, than in representative orchards in the same areas using regular commercial control schedules.
\end{abstract}

\section{Introduction}

The apple maggot, Rhagoletis pomonella (Walsh), is currently controlled in apple orchards in New York by applying an insecticide 7-10 days after adults have emerged, and subsequent sprays at 10-14 day intervals while the flies are active. These treatments are primarily applied as protection against flies immigrating into orchards from outside sources since indigenous populations in most commercial apple blocks are low or absent. If a monitoring system could be used to detect these immigrating flies, control sprays could be applied only when necessary instead of on the current protective basis.

During the past several years, different traps and lures for the apple maggot have been tested in New York State (Reissig 1974, 1975), but until recently, have been used to monitor populations and seasonal activity only in unsprayed habitats such as abandoned orchards. We report here the use of traps to determine the need and timing of apple maggot control sprays in commercial orchards in the New York apple pest management program.

\section{Materials and Methods}

Pherocon ${ }^{\circledR} \mathrm{AM}^{2}$ traps were used because they were commercially available and were as effective as other traps in capturing apple maggot adults (Reissig 1975).

Various numbers of traps/ha (Table I) were tested from 1975 to 1977 to determine if they were capable of detecting low numbers of flies infesting only a small percentage of fruit. These tests were carried out at the NYS Agric. Expt. Station (Geneva) in experimental orchards which had received normal insecticide treatments prior to 1975 . They were uninfested and near external sources of apple maggot. Small populations of flies were allowed to survive in these blocks during the test period by applying either reduced amounts of insecticides or no insecticides when the adults were active. Most of the traps were deployed along the borders of each block near the exterior sources but one or two were placed in the interior of each block to monitor indigenous flies. The traps were hung at eye level, 1/tree, near the periphery of the tree canopy. Those placed on the orchard borders were hurg on the outside edge of the trees whereas those placed in the interior were always hung in the south quadrant. Whenever possible, the traps were hung in early ripening cultivars. They were examined twice weekly for adult captures. At harvest, 100 apples/0.4 ha were examined in each block to determine fruit infestation. The same trees were sampled each year if sufficient fruit were available.

\section{Single and Multiple Block Monitoring}

In 1976 and 1977, several uninfested commercial blocks in the NYS apple pest management program in Wayne County were monitored and sprayed according to the

\footnotetext{
${ }^{1}$ Approved by the Director of the New York State Agricultural Experiment Station as Joumal Paper No. 3158.

${ }^{2}$ Manufactured by Zoecon Corp., Palo Alto, CA 94394.
} 
Table I. Relationship between the capture of apple maggot flies and harvest infestation in orchards with greatly reduced spray schedules

\begin{tabular}{lcccccccc}
\hline Orchard & Year & \# ha & \# traps & $\begin{array}{c}\text { Total flies } \\
\text { captured }\end{array}$ & \# sprays & $\begin{array}{c}\text { Spray appl. } \\
\text { dates }\end{array}$ & D.E.* & \% inf. \\
\hline $0-16$ & 1975 & 2.0 & 5 & 4 & 2 & $7 / 15,7 / 31$ & 1.0 & 1.1 \\
& 1976 & & 2 & 3 & 1 & $8 / 02$ & 0.5 & 1.6 \\
& 1977 & & 4 & 16 & 3 & $7 / 14,7 / 27,8 / 17$ & 2.0 & 0.0 \\
$0-17$ & 1975 & 3.6 & 4 & 14 & 2 & $7 / 15,7 / 31$ & $0.5 \dagger$ & 7.9 \\
& 1976 & & 5 & 11 & 2 & $8 / 02,8 / 17$ & 1.0 & 0.0 \\
$0-18$ & 1977 & & 6 & 88 & 2 & $6 / 30,7 / 14$ & 2.0 & 0.9 \\
& 1975 & 3.8 & 6 & 18 & 2 & $7 / 14,7 / 31$ & 1.0 & 1.7 \\
$0-$ LF & 1976 & & 6 & 11 & 3 & $7 / 02,8 / 02,8 / 17$ & 1.5 & 0.0 \\
& 1977 & & 4 & 148 & 3 & $6 / 30,7 / 14,7 / 27$ & 2.0 & 0.4 \\
\hline
\end{tabular}

*Dosage equivalents $=\frac{\mathrm{kg} / 378 \ell}{\text { Cornell tree fruit prod. rec. rate }(\mathrm{kg} / 378 \ell)}$

tOnly the four perimeter rows were treated.

frequency of captures. These orchards were subject to various levels of apple maggot pressure from nearby infested orchards. Traps were deployed around the perimeters of the commercial blocks as described previously and examined twice weekly throughout the season. Traps were also placed in several nearby abandoned orchards to determine the first emergence and seasonal activity of flies in Wayne County. One trap at these sites was checked daily and the others weekly throughout the season. These weekly captures were compared with those in the commercial test blocks to determine the migration of flies into the test area. No sprays were applied in the commercial test blocks until 10 days (pre-oviposition period) after the first fly was trapped in the abandoned orchards. Then, when one or more flies were captured in a test block, a spray was applied immediately, either to the perimeter rows near the traps or every other row if the infestation pressure was judged to be light. The entire block was sprayed if it was

Table II. Comparison of catches in abandoned and commercial orchards in Wayne Co., New York

\begin{tabular}{|c|c|c|c|c|c|c|c|c|}
\hline \multirow[b]{4}{*}{ Weekly interval } & \multirow{2}{*}{\multicolumn{4}{|c|}{$\%$ of total season's catch }} & \multicolumn{4}{|c|}{ 2-year total } \\
\hline & & & & & \multicolumn{2}{|c|}{ Abd. orch. } & \multicolumn{2}{|c|}{ Comm. orch. } \\
\hline & \multicolumn{2}{|c|}{1976} & \multicolumn{2}{|c|}{1977} & & & & $\%$ total \\
\hline & $\begin{array}{l}\text { Abd. } \\
\text { orch. }\end{array}$ & $\begin{array}{c}\text { Comm. } \\
\text { orch. }\end{array}$ & $\begin{array}{l}\text { Abd. } \\
\text { orch. }\end{array}$ & $\begin{array}{c}\text { Comm. } \\
\text { orch. }\end{array}$ & $\begin{array}{c}\text { Av, flies/ } \\
\text { trap }\end{array}$ & $\begin{array}{c}\text { season's } \\
\text { catch }\end{array}$ & $\begin{array}{l}\text { Av. flies/ } \\
\text { trap }\end{array}$ & $\begin{array}{c}\text { season's } \\
\text { catch }\end{array}$ \\
\hline $6 / 13-6 / 19$ & 0 & 0 & 0.0 & 0 & 0.2 & 0.0 & - & - \\
\hline $6 / 20-6 / 26$ & 0.5 & 0 & 0.1 & 1.1 & 1.1 & 0.2 & .01 & 0.9 \\
\hline $6 / 27-7 / 03$ & 3.1 & 0 & 0.8 & 1.1 & 6.1 & 1.5 & .01 & 0.9 \\
\hline $7 / 04-7 / 10$ & 6.1 & 5.5 & 8.4 & 1.3 & 30.5 & 7.7 & .03 & 2.1 \\
\hline $7 / 11-7 / 17$ & 9.9 & 3.3 & 12.7 & 3.4 & 46.7 & 11.8 & .04 & 3.4 \\
\hline $7 / 18-7 / 24$ & 30.2 & 21.1 & 13.3 & 2.7 & 73.3 & 18.5 & .07 & 6.2 \\
\hline $7 / 25-7 / 31$ & 17.8 & 11.1 & 12.9 & 6.9 & 57.2 & 14.5 & .09 & 7.7 \\
\hline $8 / 01-8 / 07$ & 11.0 & 16.7 & 15.3 & 30.1 & 55.2 & 13.9 & .30 & 27.5 \\
\hline $8 / 08-8 / 14$ & 8.1 & 35.5 & 14.3 & 23.7 & 49.0 & 12.4 & .30 & 26.0 \\
\hline $8 / 15-8 / 21$ & 9.9 & 2.2 & 7.9 & 13.3 & 33.7 & 8.5 & .10 & 11.2 \\
\hline $8 / 22-8 / 28$ & 2.4 & 4.4 & 11.2 & 8.8 & 33.5 & 8.5 & .10 & 7.9 \\
\hline $8 / 29-9 / 04$ & 0.7 & 0.0 & 2.7 & 7.5 & 10.5 & 2.6 & .10 & 6.0 \\
\hline $9 / 05-9 / 12$ & - & - & 0.3 & - & 1.1 & 0.2 & - & - \\
\hline
\end{tabular}


Table III. Use of apple maggot traps to determine the need and timing of apple maggot control sprays in New York orchards

\begin{tabular}{|c|c|c|c|c|c|c|c|c|c|c|c|c|}
\hline \multirow[b]{3}{*}{ Year } & \multirow{3}{*}{$\begin{array}{l}\text { \# blks } \\
\text { or farms }\end{array}$} & \multirow{3}{*}{$\begin{array}{c}\text { Av. } \\
\text { ha/block }\end{array}$} & \multirow{3}{*}{$\begin{array}{c}\text { Av. } \\
\text { traps/block }\end{array}$} & & & \multicolumn{4}{|c|}{ Apple maggot control } & \multirow{2}{*}{\multicolumn{2}{|c|}{$\begin{array}{l}\text { Control of } \\
\text { all pests } \\
\text { D.E. }{ }^{*} \text { block }\end{array}$}} & \multirow{3}{*}{$\begin{array}{l}\text { \% AM inf. } \\
\text { (av.) }\end{array}$} \\
\hline & & & & \multicolumn{2}{|c|}{ Flies/block } & \multicolumn{2}{|c|}{ Sprays/block } & \multicolumn{2}{|c|}{ D.E.*/block } & & & \\
\hline & & & & Range & Av. & Range & Av. & Range & Av. & Range & Av & \\
\hline \multicolumn{13}{|c|}{ A. Single block monitoring } \\
\hline 1976 & 6 & 4.4 & 5 & $0-19$ & 4.5 & $0-2.5$ & 1.2 & $0-2.1$ & 0.9 & $0.9-3.1$ & 1.8 & 0.2 \\
\hline 1977 & 11 & 3.3 & 3.7 & $0-72$ & 14.7 & $0-4$ & 2.1 & $0-3.1$ & 1.6 & $0.7-2.6$ & 1.8 & 0.0 \\
\hline \multicolumn{13}{|c|}{ B. Multiple block moritoring } \\
\hline 1977 & 7 & 14.6 & 11.0 & $2-23$ & 9.7 & $1-4$ & 2.1 & $0.2-2.7$ & 1.3 & $0.5-2.7$ & 1.9 & 0.1 \\
\hline \multicolumn{13}{|c|}{ C. Unmonitored blocks } \\
\hline 1976 & 7 & 13.1 & - & - & - & $3-4$ & 3.8 & $1,5-5.0$ & 3.1 & $1.5-5.0$ & 3.2 & 0 \\
\hline 1977 & 27 & 7.9 & - & - & - & $2-6$ & 3.7 & $1-6.3$ & 3.0 & $1-6.4$ & 3.4 & 0 \\
\hline \multicolumn{13}{|c|}{$\mathrm{kg} / 378 \&$} \\
\hline
\end{tabular}


adjoining a heavily infested outside source. Spray residues were estimated to provide control for the next 10 days and additional sprays were only applied if flies were trapped after the protective period. Each year, five randomly selected trees in each block were sampled at harvest to determine the effectiveness of the treatments. One hundred fruit near the top of the tree, 100 from the middle, and all drops (up to 100) were examined for apple maggot infestation.

In 1977, complete farms or groups of adjacent blocks in the NYS apple pest management program were monitored as a single unit. Traps were not placed in every block but were deployed along the edges of key blocks located near the most serious potential outside infestation sources. The same procedure described for single block monitoring was followed except that all blocks on a farm were treated whenever flies were captured. The block or area where the flies were trapped usually received a complete spray at the full recommended rate. Other areas of the farm were sprayed at reduced rates or only the $4-5$ perimeter rows or every other row were treated. The effectiveness of the treatments was evaluated in the same manner as that described for single block monitoring.

\section{Results and Discussion}

The monitoring tests in experimental orchards treated with reduced amounts of pesticides showed that the traps were sufficiently sensitive to detect small populations of apple maggots since flies were captured in all blocks even when only trace amounts of fruit were infested (Table I). Infestation levels were not directly related to numbers of captured flies, and infested fruit was found even in blocks in which only a few flies were trapped. This indicated that it would be necessary to apply a control spray in monitored blocks in commercial orchards whenever even one fly was captured to completely prevent subsequent fruit damage.

The first fly was captured in abandoned orchards in Wayne Co. on 23 June, and 18 June, respectively, in 1976 and 1977. The subsequent seasonal activity of flies in unsprayed orchards was also different each year, but peak captures generally occurred in late July (Table II). Few flies were caught in commercial orchards before mid-July and most were trapped during the first 2 weeks in August. These catches demonstrated that indigenous populations of flies were low in the monitored commercial orchards and most flies immigrated into these blocks shortly after the peak activity had occurred in unsprayed habitats. A similar pattern of capture of apple maggots in commercial New York orchards was previously reported by Reissig (1975).

Captures of flies and subsequent control sprays and dosage equivalents applied in single blocks and farms where monitoring tests were conducted varied considerably because of varying degrees of apple maggot immigration pressure from outside sources (Table III). However, an average of 69,43 , and $43 \%$ fewer sprays and 71,47 , and $57 \%$ less insecticide was applied for apple maggot control, respectively, in the single blocks monitored in 1976, 1977, and farms monitored in 1977 (Table III A,B), than in representative orchards in the same area not under pest management in which normal control measures were applied (Table III C). Commercially acceptable control was obtained in all monitored orchards, although trace infestations occurred in several blocks.

This work has shown that currently available traps can be used successfully in commercial orchards in New York to determine the need and timing of apple maggot control sprays, although considerable expertise and labor is necessary to set up and maintain the monitoring systems, particularly on a single block basis. Similar promising results have been obtained with these traps in Canadian orchards (Trottier et al. 1975; Neilson et al. 1976). In the future, these traps can probably be used more widely in NY State orchards to reduce the amount of insecticides applied annually for apple maggot 
control as more pest management personnel become available and growers and chemical fieldmen are trained to maintain and deploy the systems.

\section{Acknowledgments}

We thank D. C. Bruno, D. E. Way. J. M. Misiti, and J. D. Corser for technical assistance during this study.

\section{References}

Neilson, W. T. A., I. Rivard, R. Trottier, and R. J. Whitman. 1976. Pherocon ${ }^{\mathrm{R}}$ AM standard traps and their use to determine spray dates for control of the apple maggot. J. econ. Ent. 69: 527-532.

Reissig, W. H. 1974. Field tests of traps and lures for the apple maggot. J. econ. Ent, 67: 484-486.

1975. Evaluation of traps for apple maggot in unsprayed and commercial apple orchards. J. econ. Ent. 68: 445-448.

Trottier, R., I. Rivard, and W. T. A. Neilson. 1975. Bait traps for monitoring apple maggot activity and their use for timing control sprays. J. econ. Ent. 68: 211-213.

(Received 18 April 1978) 